\title{
Organizing in the Anthropocene
}

\begin{abstract}
The functioning of the biosphere and the Earth as a whole are being radically disrupted due to human activities, evident in climate change, toxic pollution and mass species extinction. Financialisation and exponential growth in human production, consumption and population now threaten our planet's life-support systems. These profound changes have led Earth System scientists to argue we have now entered a new geological epoch; the Anthropocene. In this introductory article to the special issue we firstly set out the origins of the Anthropocene and some of the key debates around this concept within the social and physical sciences. We then explore five key organizing narratives that inform current economic, political, social and cultural understandings of the Anthropocene and link these to the contributions in this special issue. We argue that the Anthropocene is the crucial issue for organizational scholars to engage with to understand on-going anthropogenic problems and help to create alternative forms of organizing based on realistic Earth-human relations.
\end{abstract}

Keywords: Anthropocene; Earth systems; organizing; narratives; capitalism

\section{Introduction}

Human civilization has now irrevocably altered basic Earth systems. Two centuries of industrialisation and economic globalization based upon the rapacious exploitation of fossil fuels, and the destruction of forests, lands, oceans and cultures has disrupted the Earth's atmosphere and ice caps and devastated the biosphere. This has occurred at such a scale and pace that Earth scientists argue we are leaving the Holocene geological epoch and entering the more volatile 'Anthropocene'. This is a period in which human activity has discernibly affected 
the Earth's global functioning to such an extent it is now operating outside the range of any previous natural variability (Crutzen, 2002; Steffen, et al., 2007). These changes breach planetary boundaries and reduce or eliminate the 'safe operating space for humanity' (Rockström, et al., 2009: 472), including: a step-change in the average temperature of the planet this century of around 4 degrees Celsius (New, et al., 2011); the sixth great species extinction in the geological record (Kolbert, 2014); the acidification of oceans; the disruption of the nitrogen and phosphorus cycles; and the pollution of air and water with a range of chemical and radioactive toxins (Whiteman, et al., 2013). Extreme weather events, sea-level rise, food and water shortages, and accompanying political conflicts and wars suggest that life this century for much of the planet's population is likely to be increasingly hard, violent and precarious (Dyer, 2010). The implications for organizations and organizing could not be more profound.

Recognising that human activity has discernibly changed the Earth's global functioning has revolutionary implications for our understanding of ourselves and the globally-integrated, growth-based, fossil-fuelled organizations on which much of the world's population relies. While organizational scholars have for some time focused on the natural world as a context for business activities (see e.g. Bansal and Hoffman, 2012), far fewer have sought to adopt a critical approach to the way in which changing Earth systems affect how we understand organizing and organizations (for exceptions see e.g. Ergene, et al., forthcoming; Gosling and Case, 2013; Whiteman, et al., 2013; Wright and Nyberg, 2015). In this special issue of the journal Organization we invited scholars to reflect on the huge and diverse implications that the Anthropocene brings to our understanding of organizations and organizing. The goal with the special issue was two-fold: i) to stimulate the organization studies community to engage in discussions about the concept of the Anthropocene, and ii) to stimulate Anthropocene scholars 
to think further about the politics of the Anthropocene by considering how organizations and organizing underpin how human societies will respond in this new geological epoch.

In this introductory editorial article we firstly provide some necessary background context on the concept of the Anthropocene, before exploring some of the highly contested debates about the Anthropocene and how we understand its causes and implications. We then set out five different narratives of Anthropocene organizing which a number of the papers in our special issue engage with. We label these: (i) organizing economics - business as usual; (ii) organizing technology - the ecomodern 'Good Anthropocene'; (iii) organizing resistance: climate mobilization and social justice; (iv) organizing alternatives: new forms of social organization; and (v) organizing culture - the Anthropocene and the imagination. We conclude the article by highlighting areas where organizational scholars can make significant future contributions to our understanding of the Anthropocene and demonstrating how organizations and organizing are central to our understanding of humanity in a world increasingly altered by human actions.

\section{Anthropocene as scientific phenomenon}

The concept of the Anthropocene emerged out of the interdisciplinary work of the International Geosphere-Biosphere Program (IGBP) that, from 1987 until 2015, acted as a hub for the analysis and visualization of global environmental change (see Crutzen and Stoermer, 2000). More recently the Anthropocene has become the key concept in the IGBP's successor, Future Earth, particularly among Earth System Scientists. Within this relatively new discipline of Earth System Science (ESS), the Anthropocene is the name given to a new 'operating state' of the planet triggered by the human species - a state which has intensified over time.

Far more serious than just a changed climate, this is about cascading shifts in five interacting subsystems of the Earth: the atmosphere, hydrosphere, cryosphere, lithosphere and 
biosphere, with humans being one species among a dwindling number in the latter. In the lexicon of ESS - based in complex adaptive systems science -the Earth system has begun to leave its 'basin of attraction' as some of the negative feedbacks that have kept the planet relatively stable over the last 12,000 years of the Holocene break down. Positive feedbacks (those that amplify, not dampen change, such as the melting of methane-rich permafrost under global warming) are beginning to push the Earth towards multiple tipping points and an overall major 'state change' (Steffen, et al., 2016). The speed and scale of planetary change described by these trends throws deep uncertainty over the future of the biosphere of which humans are a part - in this new epoch, fundamental indeterminacy and volatility have begun to characterise how the planet functions.

The idea of the Anthropocene has triggered an outpouring of scientific research, with new journals dedicated to the idea (Anthropocene, Anthropocene Review and Elementa). Why has this still hypothetical idea of the Anthropocene triggered such enthusiasm within the scientific community? Some key characteristics of the idea offer clues. First, the Anthropocene provides a powerful 'boundary object' for researchers working on different aspects of environmental change. For example, the concept connects climate change to species extinction and soil degradation; it links the polluting effects and plant usage of phosphorous to wider planetary change. As such, the Anthropocene provides an organizing conceptual framework and institutional rationale for knowledge integration and interpersonal collaboration of the sort already encouraged in the contemporary academic world. It calls for deeper cooperation and integration between the various branches of science, social science, humanities and arts, in recognition of the limitations of dividing the academy along Nature and Society lines. The concept thus helps give context and meaning to the work that individual scientists are doing, placing their research within an overarching narrative. 
Second, underpinning the idea that the Earth (including humans) has significantly changed, is the ESS finding that the planet functions as a single system. This deepens our understanding of global change by demonstrating that the whole planet is interconnected, and that the regions of the Earth from its crust to the outermost reaches of its atmosphere have been profoundly disrupted by human industrial activity. The Anthropocene thus poses a range of intellectual challenges to science: for example, that purely inhuman nature - the imagined object of most science - was never a valid construct because the human was always an inextricable element in the view of nature. By eliminating the Cartesian categorical opposition of humans and nature, at the same time as revealing the far-reaching influence of the former, the Anthropocene demands new reflection on ontological, epistemological and methodological assumptions in Western society and the development of more integrated approaches to knowledge production.

Third, the Anthropocene helps validate and legitimate the value of science. As a discovery, the idea of an integrated Earth system is profound, being presented by some as a scientific revolution akin to the Copernican Revolution (see Angus, 2016). Moreover, the Anthropocene exemplifies the social relevance of science, helping boost its role as a source of collective truth and a potential guide for social organization. The idea of the Anthropocene emerges at a time when it has become clear that financial and political institutions are failing to decarbonize the global economy or respond appropriately to climate change. Some authors of the Anthropocene explicitly hope that the concept will trigger renewed efforts to tackle the planetary crisis in a more coordinated, sophisticated and effective way. Scientific impartiality and authority is seen as an important basis for such hopes, but the situation also demands greater reflexivity and engagement by scientists with the political implications of a growthbased and globalized socio-economic system (Bagley, 2016). The planetary scale and complexity of the crisis society now faces reinforces the need for Earth-level scientific 
guidance. Some scholars have responded with calls for Earth System Governance (Biermann, et al., 2012), although others caution that the very notion of 'Earth System Governance', however well-intentioned, is itself a potentially hubristic idea (e.g. Lövbrand, et al., 2009).

Overall, the Anthropocene idea is at the centre of a reorganizing of scientific enterprises, knowledge and authority. Whether these various shifts help actually address (or possibly reinforce) the underlying drivers of the new Anthropocene condition remains to be seen. Meanwhile, the idea has also triggered an outpouring of scholarly and popular responses outside of the natural sciences, to which we now turn.

\section{Anthropocene as social (science) 'scene'}

The social dialogue about the Anthropocene has been taken up as an organizing context in a wide range of scholarly and popular work, leading to a host of publications, media, artwork and events, in what some have termed a broader Anthropo-scene (Castree, 2015a; Lorimer, 2017). In addition to fertilizing scholarship and creative practices in various arenas, the Anthropocene is the focus of intensive engagement by various branches of social science seeking to help research, understand and come to terms with the meaning of this 'Age of Humans'. The idea that everything exists within coupled social-ecological systems is seen to necessitate close 'social science-physical science' collaboration which, in turn, requires learning and compromise in both directions, and discussions about scale, knowledge and politics (Biermann, et al., 2016; Palsson, et al., 2013).

For instance, commentators such as Noel Castree and Clive Hamilton have taken a keen interest in the knowledge production practices around the Anthropocene and offer feedback as 'critical friends'. Castree has written extensively on the intellectual and institutional relationships involved in the making of Anthropocene science and enjoined social scientists to develop a greater degree of critical reflexivity and temper some scientists' over-enthusiasm for 
prescriptive solutions to their diagnosis of the Earth condition (e.g. Castree, 2015b; 2017). Hamilton has been more directly involved in the scientific debates (Hamilton, 2015; 2016; Hamilton and Grinevald, 2015) as well as social science Anthropocene literature (Hamilton, 2017; Hamilton, et al., 2015), trying to correct what he sees as misinterpretations of Anthropocene science. Hamilton notes, for example, that the Anthropocene is not about gradual global 'environmental change', but is rather a profound functional shift in the Earth system.

However, the key area of social science scholarship on the Anthropocene adopts a more critical focus towards the concept while accepting the basic message that the planet is now fundamentally and dangerously altered. Here, STS and environmental politics scholars such as Eva Lövbrand highlight the social constructedness and political character of the Anthropocene concept, pointing to its emergence from a particular, historically situated context, one dominated by a modernist and masculinist form of global science. By appreciating the positionality of Anthropocene science, they argue, we are better able to understand and critique the proposed solutions such scientists have taken upon themselves to suggest, namely a reliance on elite science-led international institutions for 'Earth stewardship', including 'engineering' the climate (Lövbrand, et al., 2015; Uhrqvist and Lövbrand, 2014).

Added to this, a large thread of social science literature on the Anthropocene critiques the reductive and linear version of human history embedded in the dominant Anthropocene narrative. Of prime concern here is the assumption that the human species as a whole has been responsible for this trajectory, and that the consequences of this impact lie in the future. As eco-socialist and environmental justice scholars point out, what is obscured in such historical representations, is not only that not all humans are responsible for the environmental damage that has been caused, but that many humans and nonhumans have already been sacrificed along the way, including many peoples whose lives demonstrated that human degradation of nature is not a natural inevitability (Di Chiro, 2016; Hamilton, et al., 2015; Malm and Hornborg, 
2014). Far from being the outcome of a generic Anthropos, this critique argues, the tragedy of the Anthropocene was initiated and remains driven by a powerful and unethical subset of society, whether understood as the capitalist class, oligarchs, or Anglo-Saxon nations, to name some of the groups held primarily responsible for destroying the habitability of the planet (Angus, 2016; Haraway, 2015; Moore, 2016).

This more critical analysis of the Anthropocene is particularly pronounced amongst eco-socialist scholarship which, drawing on a deeper political economy perspective, demonstrates how the Anthropocene is a product of capitalist economic relations and the dramatic changes unleashed over the last two centuries of fossil-fuel based industrialization (Angus, 2016; Foster, 2015b; Malm, 2016). Drawing on Marx's original insights, the development of capitalism as the dominant economic model of human development is argued to have unleashed a 'metabolic rift' in the relationship between humans and the earth, resulting in an environmental crisis that now threatens the very basis of life on the planet (Foster, 2000).

In the Anthropo-scene of social thought and activism, the Anthropocene contains and has stimulated very different impressions of the world, different human roles, and divergent proposals about what we are to do. As both a material condition and concept, it demonstrates the performative power of different ways of knowing and intervening in the world. This reminder of the unruly mixture of rational, intentional, unconscious and fantastic elements in human worldviews has prompted a re-examination of the implications of the Anthropocene for different areas of academic knowledge production, including the question of 'what type of Anthropocene' such knowledge work (inadvertently) helps produce. Thus, the Anthropocene demands we return to the perennial question of how to think about organizing and the conscious and unconscious operation of power in and through human institutions. The following section discusses five different readings of organizing the Anthropocene and how these readings shape responses. 


\section{Organizing Anthropocene futures}

Building upon the idea of different understandings, framings and narratives of the Anthropocene illustrates the widely divergent possibilities for organizations and organizing in this new epoch. Indeed, given the import of what Earth system scientists have identified, organizations and organizing underpin not only the creation of this new era in our planet's geological record, but also how different aspects of society will respond. In this section of the paper, we set out five different narratives of organizing in the Anthropocene with which the papers in this special issue engage. These five narratives provide insight into some of the key organizing dynamics that seem likely to play out in coming decades in terms of economic, technological, political and cultural dimensions.

\section{(i) Organizing economics: business as usual}

The first and possibly dominant narrative of organizing in the Anthropocene is based upon an assumption that the current neoliberal agenda of business expansion and growth will continue, albeit with some variations as ecological and geopolitical circumstances deteriorate. Indeed, while the topic of the Anthropocene has captured the imaginations of intellectuals and researchers across both the physical and social sciences, in corporate boardrooms, political offices and mainstream media there is little if any acknowledgement of the huge ecological transformations humanity and other species face due in large part to the 'business as usual' trajectory. For global business and political elites (and the economics, finance and management professions which underpin them), the Earth continues to be viewed as simply a source of natural resources and a sink for the disposal of our economies' waste.

A good example of this 'business as usual' lock-in is to consider the response of industrialised nations to the worsening crisis of anthropogenic climate change. Despite 25 years 
of vigorous climate diplomacy (beginning with the Earth Summit in Rio de Janeiro in 1992), and the creation of a variety of national and international organizations and agreements seeking to deal with the climate crisis (Gupta, 2014), there has been little to no discernible change in the rate of growth of global greenhouse gas (GHG) emissions (Jackson, et al., 2017). Rather, in the intervening years we have witnessed an acceleration of global industrial expansion, the opening up of new carbon frontiers and the exploitation of unconventional fossil fuels such as new mega and mountain-top coal mines, deepwater and Arctic oil drilling, tar sands processing and the explosive growth of shale and coal seam gas fracking around the world (IEA, 2013; Kitchen, 2014). Rather than stepping back from the abyss of dangerous climate change, political and business elites have over the last two decades doubled down on the fossil fuel bet, perhaps most evident in US President Trump's decisions to wind back environmental protections, reject climate diplomacy and open up the North American continent to expanded fossil fuel extraction (Tollefson, 2017).

For many critics, this continued degradation of ecosystems and the reconstitution of the chemistry of the atmosphere and oceans is not a product of unscrupulous businesses and governments, but an inherent feature of the expansion of global corporate capitalism which is reliant upon continued compound growth. As Wright and Nyberg (2015) have argued, corporate and political elites are now engaged in a process of 'creative self-destruction' in which the relentless pursuit of new global markets, the expansion of consumption and new forms of capital accumulation risk the demise of entire ecosystems and indeed, a habitable climate for human civilization. Indeed, the worsening climate crisis highlights how neoliberal economic reform and the promotion of globalised trade are fundamentally in conflict with the need for radical decarbonisation of the world's energy system (Klein, 2014).

As a result, one powerful organizing narrative in the Anthropocene is a continuation of the very model that has unleashed the multiple ecological crises we now face. In this business 
as usual narrative, the nations, institutions and corporations with the greatest financial power are seen as collaborating to maintain policies aimed at maximising industrial growth and the extraction and use of fossil fuel-based energy for as long as possible (Levy and Spicer, 2013). Critics point to the likelihood of increasing state coercion in the maintenance of private capital; what Klein (2007) has termed 'disaster capitalism'. For instance, many G20 nations have begun to categorise civil protest and environmental activism as threats to national security (Ahmed, 2014; Potter, 2011). Thus, just as resource extraction is often enforced by coercive state control and the use of violent force (Banerjee, 2008), so heightened social conflict over 'business as usual' practices may result in increasingly authoritarian responses and a reliance on governments protecting corporations' economic interests. Such a future Anthropocene narrative involves growing economic and political inequality and organizing by powerful global elites around the attempt to insulate their interests from broader collective well-being.

\section{(ii) Organizing technology: the ecomodern 'Good Anthropocene'}

While economic and political interests ignore the biosphere dynamics of our changing world, a second Anthropocene organizing narrative portrays an apparently optimistic and heroic role for markets and technology in averting ecological collapse. Emerging in recent years under the labels of the 'new environmentalism' and 'ecopragmatism' (Shellenberger and Nordhaus, 2004; 2011), this ecological modernist perspective offers a exuberant vision of human ingenuity in dealing with environmental challenges.

As an organising narrative of the Anthropocene, ecomodernism stresses the need for increased economic development and technological innovation as a way of minimising planetary harm (Mol, 2002). Underpinning this view is a belief that new technologies and markets can decouple financial growth from environmental destruction in both relative and absolute terms (Jackson, 2009). At a policy level, former World Bank chief economist Sir 
Nicholas Stern (2007) offered a classic illustration of this view when he famously characterised climate change as a market failure and proposed that the pricing of carbon emissions (defined as 'externalities') would enable the market to correct itself. Beyond the embrace of marketbased solutions to climate change, biodiversity decline and deforestation through the valuation of so-called 'ecosystem services' (Farber, et al., 2002), the large-scale adoption of new technologies such as genetic engineering, nuclear power and 'geoengineering' are seen in this narrative as necessary responses to the biospheric crises of the Anthropocene.

For instance, groups such as the Breakthrough Institute, a California-based think-tank, have called for the reinvention of environmentalism 'for the 21 st century' through a conviction that technologies such as genetic engineering, nuclear power and 'geoengineering' can be harnessed to the advantage of both humanity and 'the environment' (Shellenberger and Nordhaus, 2004; 2011). Indicative of this argument, Stewart Brand, a Breakthrough Institute member and key figure in California's silicon valley, has argued that 'We are as gods and HAVE to get good at it' (Brand, 2009: 1). Indeed, some 'ecopragmatists' have gone as far as to proclaim a so-called 'Good Anthropocene', in which humans continue to manipulate the environment to suit ever-distending consumption and population (Ellis, 2011; Revkin, 2014). In this good Anthropocene, 'the environment will be what we make it' (Ellis, 2013: A.19). Such a stance rejects the notion that extant economic and social structures need to be rethought: enterprise and corporate capitalism are championed as the optimum means of delivering the innovation that will guarantee our lasting prosperity.

This optimistic vision of the Anthropocene has also found ready application within the business world through the practices of 'corporate environmentalism' and business sustainability (Hoffman, 2001; Jermier, et al., 2006), in which companies are presented as responding to environmental problems through their innovative capacity and profit motive. This has involved improving eco-efficiency to reduce energy consumption and operational 
costs, increasing supply-chain efficiency, developing new 'green' products and services, and marketing organizations as environmentally responsible in order to better attract and retain employees and build stronger customer relationships (Hart, 1995; Porter and van der Linde, 1995; Russo and Fouts, 1997). Unlike neoclassical economics in which environmental protection is viewed as a threat to profitability (Friedman, 1970), corporate environmentalism promotes a 'win-win' vision of businesses augmenting profits by improving environmental performance; in short, 'do well by doing good' (Falck and Heblich, 2007; Porter and Kramer, 2011).

The ecomodernist narrative of the Anthropocene also opens up space for entrepreneurial endeavour as businesses searches for ways to 'manage' ecosystems and global environments (Funk, 2014). So for instance, growing business interest in 'geoengineering' highlights the belief that corporate innovation and technology can remake the world in an image that maintains economic growth and capitalism. Proposed geoengineering initiatives include regulating solar energy through spraying sulphate particles into the upper atmosphere; 'brightening' clouds to improve the 'albedo effect'; and seeking to extract GHGs from the atmosphere through reforestation and industrialised carbon capture (Hamilton, 2013; Keller, et al., 2014). Although most proponents insist these are measures of last resort (Clark, 2014), the emphasis on geoengineering also provides an excuse for the lack of action in reducing GHG emissions. Indeed, as Lederer and Kreuter (forthcoming) outline in this special issue, there are serious doubts about humanity's collective ability to legally regulate geoengineering initiatives in an era of growing ecological crisis (see also Szerszynski, et al., 2013). Technological geoengineering proposals thus provide a dramatic example of the faith of corporate and political elites in the power of markets and technology in organizing the Anthropocene.

(iii) Organizing resistance: Climate mobilization and social justice 
While the previous two organizing narratives justify and promote a continuation of existing economic relations, a third emerging Anthropocene narrative explicitly challenges these assumptions. Consisting of a diverse range of non-government organisations (NGOs), grassroots activists, local communities, religious institutions, charities and indigenous communities, the climate mobilisation movement stresses the need for urgent and radical reductions in carbon emissions, the rejection of new carbon frontiers and extractivism, and employs a range of strategies including political action, protest, civil disobedience and community engagement (for an overview see Dietz and Garrelts, 2014).

Building on an earlier tradition of environmentalism which highlighted the industrial degradation of nature (Carson, 1962; Radkau, 2014), climate mobilisation emphasises the existential threat posed by humanity's reliance on fossil fuel-based energy and ever-expanding consumption. As Bill McKibben (2012) has argued, the mathematics of the climate crisis are simple. Humanity has a set 'carbon budget' if global warming is not to exceed $2^{\circ}$ Celsius; we have already burned two thirds of this budget, and the remainder is exceeded more than fivefold by remaining reserves of fossil fuel; therefore around 80 per cent of known fossil fuels must stay in the ground.

This 'simple maths' raises fundamental economic and political concerns. First, the political recognition that most currently identified fossil fuels are unrecoverable if a habitable climate is to be maintained raises the likelihood of a 'carbon bubble' and 'stranded assets' (Carbon Tracker Initiative, 2012). Second, recognition of the fundamental conflict between continued fossil fuel extraction and humanity's future has driven a growing political movement for fossil fuel divestment in which activists seek to weaken the fossil fuel industry financially and politically (Ansar, et al., 2013). Popularised by NGO 350.org through a programme directed at US colleges and local government, fossil fuel divestment has swiftly gained international traction and earned the backing of many high-profile organisations including 
Stanford University, the cities of Seattle, San Francisco and Portland, the World Council of Churches, Glasgow University, the British Medical Association and, perhaps most symbolically, the Rockefeller Foundation.

Organizing resistance in the Anthropocene has also involved direct opposition to proposals for new fossil fuel developments, extractivism and civil disobedience (della Porta and Parks, 2014). So for example, Greenpeace, has spearheaded campaigns against oil extraction in the Arctic (Vidal, 2014); UK group Plane Stupid has occupied London's Heathrow Airport to condemn the climate impact of an ever-growing airline industry (Topham, 2016); and indigenous communities and NGOs have led protests and occupations to delay the US government's construction of oil pipelines (Bradshaw, 2015). This opposition has also emerged spontaneously from within local communities rising up against the destruction of their local ecosystems. Klein (2014: 293-336) has characterised this phenomena as 'Blockadia' evident in Greek villagers protesting the destruction of their forests by a Canadian mining company; running battles between police and anti-fracking protesters in Romania and England; indigenous communities fighting oil extraction in the Amazon; blockades against new megacoal mines in Australia; and protests and sit-ins over proposed pipelines to transport Canadian tar sands bitumen to processing plants in the southern US and export terminals in British Columbia. Across diverse locations, companies accustomed to buying consent with the promise of jobs and government royalties are facing concerted resistance that goes beyond traditional localism.

This comes at a time when local communities are also confronting the physical impacts of the Anthropocene. For coastal populations now exposed to increasingly severe storms, flooding and sea-level rise, rural communities confronting record-breaking droughts and fires, or urban centres dealing with summer heat-waves and power outages, adapting to the shifting baselines of a changed climate will require new forms of social interaction and collaboration 
(IPCC, 2014; Newman, et al., 2017). However, as Wissman-Weber and Levy's (forthcoming) study of climate change adaptation in Boston shows, certain actors and interests are privileged over others. Even in places of organized adaptation, impoverished communities are disproportionately exposed to extreme weather events, with consequences such as failing infrastructure and service provision (Houston, 2013; Scranton, 2015). Here, a newly emerging social movement for 'climate justice' is evident in a wide range of communities focused on local environmental impacts and vulnerabilities, inequality of resources and demands for community action and control (Schlosberg and Collins, 2014). This focus on the intersection of climate and environmental justice highlights the reality that the poor and economically marginalised around the world are not only the most vulnerable in the Anthropocene era, but also the least responsible for contributing to it.

Finally, the organization of resistance has also recommenced the discussion of how Western legal systems treat nature as property in making the Earth invisible to the law. Following on from Stone's (1974) argument to give nature rights of personhood, there is an international rights-of-nature movement aiming to protect the natural world through legal means. For example, in 2008 Ecuador became the first country to protect the rights of nature in its constitution and New Zealand has granted legal personhood to a forest (Te Uruwera forest in 2014), a river (Whanganui river in 2017) and a mountain (Mount Taranaki in 2017). As Kalonaityte (forthcoming) explores in her article in this special issue, this development could encourage more radical experimentation in challenging the foundational assumptions of our societies.

(iv) Organizing alternatives: new forms of social organization

This brings us to our fourth Anthropocene narrative, organizing possible social alternatives beyond the continuation of fossil-fuel based economic growth. Here, academic work has 
focused on grounded practices that demonstrate ontologies that do not assign humans, other life forms or wider reality into normatively fixed roles (Buck, 2015; Collard, et al., 2015; Ginn, 2015). These include practices of regenerative food production, alternative community economies, new ways of communing, and experiments in organizing social-ecological life along more regenerative, equitable and ethical lines (Gibson Graham and Roelvink, 2010; Gibson, et al., 2015; Lorimer, 2015; Roelvink, 2013).

Practically, this has involved communities and individuals setting out possible alternatives to the current dominance of top-down, industrial development. So for instance, examples such as community-owned renewable energy production (Maruyama, et al., 2007; van der Schoor and Scholtens, 2015), 'transition towns' (Smith, 2011), food cooperatives and concepts such as the 'circular economy' (Murray, et al., 2017) are increasingly promoted by communities as more sustainable economic models to follow. For instance, the contributions to this special issue by Beacham (forthcoming) and Roux-Rosier et al. (forthcoming), have a specific focus on alternative food networks and permaculture as different potential forms of Anthropocene organizing. More broadly, the environmental movement and others have also started to explore possibilities for a ‘just transition' away from fossil fuel based energy systems including alternative employment options that can be generated in the switch to communitybased renewable energy systems (Evans and Phelan, 2016). This extends to a broader vision for the transformation of social and economic relations as evident in the formation of groups such as the Climate Justice Alliance (Quinn-Thibodeau and Wu, 2016), which has highlighted the need for co-operation across traditionally separated policy concerns such as energy, housing, transport and poverty alleviation.

However, more negative depictions of future social organization also dominate visions of our Anthropocene future; a post-Enlightenment fatalism in which complexity is overwhelming and all hope for positive human intervention has been abandoned (Foster, 
2015a; Hamilton, 2010; Scranton, 2015). In this light, the Anthropocene unhelpfully exposes the futility of human ambition and all that is left is for each individual to be as resilient as they can be, with little point in collectively trying to improve conditions. Endorsement of this more negative Anthropocene fatalism is pronounced in social movements such as the Dark Mountain Project which stresses how the totality of ecocide requires an acceptance of the inevitable collapse of human civilization (Kingsnorth and Hine, 2009). Rather than hope, advocates for an alternative future point to the need for courage in fighting against the vested interests that have precipitated our current impasse. As fossil fuel activist and former political prisoner Tim DeChristopher has argued:

'Once I realized that there was no hope in any sort of normal future, there's no hope for me to have anything my parents or grandparents would have considered a normal future - of a career and a retirement and all that stuff — I realized that I have absolutely nothing to lose by fighting back. Because it was all going to be lost anyway.' (Williams, 2012)

\section{(iv) Organizing culture: the Anthropocene and the imagination}

Our final organizing narrative focuses on the cultural framings of the Anthropocene evident in art, aesthetics, literature, advertising and popular culture. In contrast to the four previous organizing narratives, self-organizing cultural responses to the Anthropocene offer new and potentially far more extensive ways of 'seeing, sensing, thinking, and dreaming that creates the conditions for material interventions in, and political sensibilities of the world' (Yusoff and Gabrys, 2011: 516).

A burgeoning range of diverse cultural engagements with the idea of the Anthropocene are occurring. Anthropocene art and literature has already begun to develop new forms of language, and representation for this new era. Initiatives have included attempts at developing 
a new vocabulary for the Anthropocene (Quant and Escott, 2017), as well as a plethora of visual art, murals, and installations expressing the diverse physical-emotional implications of an era of mass species decline and ecocide (Davis and Turpin, 2015; Granada, 2017). These works often have a clear political purpose in raising public awareness of the reasons for the worsening state of the Earth, and tapping into the loss and grief ('solastalgia') many feel at the despoiled planet rendered for our children (Albrecht, et al., 2007). For example, visual artist Jill Pelto (2017) has developed what she terms 'glaciologenic art' which includes watercolour paintings of nature transposed in the form scientific graphs of glacier decline, ocean acidification and deforestation. As she notes, 'Art is a uniquely articulate lens: through it I can address environmental concerns to raise awareness and inspire people to take action.'

Fiction and creative non-fiction writers have also been at the forefront of recent cultural framings of the Anthropocene (Kaplan, 2016; Trexler, 2015; Ullrich, 2015). For instance, the burgeoning genre of climate fiction ('clifi') has enjoyed significant recent popularity evident in bestsellers such as Margaret Atwood's Maddadam trilogy (2003; 2009; 2013), Barbara Kingsolver's Flight Behavior (2012) and James Bradley's Clade (2015). These fictional stories provide insights into an imagined Anthropocene future in which our comfortable assumptions of the natural world are upturned and individuals and communities are confronted with a radically different and often catastrophic context for survival. This dystopian imagining of the Anthropocene is reinforced through non-fiction accounts of current environmental destruction and projections of future scenarios such as climate scientist James Hansen's Storms of My Grandchildren (2009), environmental activist Bill McKibben's Eaarth (2010), or journalist Elizabeth Kolbert's The Sixth Extinction (2014).

The self-organizing cultural response to the Anthropocene is also evident in film and literature. For instance both fictional motion pictures (e.g. The Day After Tomorrow, Interstellar) as well as growing number of documentary films such as An Inconvenient Truth 
(Guggenheim, 2006), The Age of Stupid (Armstrong, 2009), Gasland (Fox, 2010), and Before the Flood (Stevens, 2016) highlight both current environmental challenges that our world now faces as well as projecting where our Anthropocene future may lead. Linked to powerful celebrity voices such as Al Gore or Leonardo Di Caprio these representations of ecological crisis have reached large global audiences and reshaped public understanding of our reliance on the natural world (Boykoff and Goodman, 2009).

Of course, the most pervasive and intrusive cultural framing of Earth-human relations is evident in corporate advertising, marketing and public relations which portray consumercapitalism, technologies and innovation taming uncertainty to ensure human well-being (see for e.g. Garland, et al., 2013). Here, 'a future world of underwater tidal energy farms, jet planes with birds' wings and trains that move in unison with swaying trees' (Wright and Nyberg, 2015: 151) is presented as an omnipotent fantasy to justify the continuation of current economic logics and silence more critical and challenging accounts (Freund, 2015). This serves four linked purposes: to spread confusion and cynicism concerning environmental critique; to absorb and defang the threat that alternative Earth-centric cultures pose to globalizing capitalism; to make profit; and to legitimise the prevailing economic and financial system. Through these cultural interventions, financial institutions, corporations and national governments portray a rose-tinted future in which the hyper-consumerism of the present continues ad infinitum, and magically produces a secure anthropocentric future of high-energy technological and industrial progress (Freund, 2014).

\section{Conclusion}

This article began by describing what the Anthropocene may be, and how this new era has emerged from the assumed schism between humans and the rest of the Earth. The Anthropocene thus forcefully reminds us that the main function of human economic and 
cultural organizations is to bolster this imaginary schism that humans en masse wish was there to protect us from the complexities and threats of living on Earth. The most prominent and biospherically damaging institutional manifestation of this desire to dominate and transcend the Earth is the global spread of consumer-capitalist growth-based organizing that has precipitated the Anthropocene. The above five types of Anthropocene narratives outline the contours and fault lines of probable, early Anthropocene political battlegrounds, and the defensive techniques that economic elites are adopting to divert, neutralize, undermine and/or repurpose the research and activism that can help us with the task of minimising harm and changing course.

The articles in this special issue are in different ways working this fault line between how we uphold the dominant imaginary of a separate existence from Earth systems and the radical re-thinking needed in learning to live in the Anthropocene. Lederer and Kreuter (forthcoming) show how the promise of climate engineering supports 'business as usual' by assuming that these developments can be regulated through legalistic means. However, rather than challenging the conceptualization of nature, climate engineering is likely to play into the current hubris of human agency on Earth (Rickards, 2015). Similarly, Wissman-Weber and Levy (forthcoming) show the dominance of 'business as usual' in their case study of climate change adaptation in Boston. Their analysis challenges rational and objective theories of risk that assume predictability and linearity. In contrast, they conclude that the new epoch of the Anthropocene is shaping our understanding of risk and that current thinking is likely to be inadequate to prevent disastrous climate events (see also Nyberg and Wright, 2016). Both of the articles by Lederer and Kreuter (forthcoming) and Wissman-Weber and Levy (forthcoming) outline competing imaginaries of climate engineering and sea-level rise respectively within a context in which the business as usual approach is still dominant. Their 
cases thus illustrate the importance of developing and supporting alternative ways of organizing society.

This is the task the three remaining articles in the special issue direct themselves towards. For instance, drawing upon Rancière, Kalonaityte (forthcoming) develops a framework to challenge the business as usual organizing narrative and configure what is sayable by, for example, mobilizing support for new political subjects, undermining current categorizations and demanding rights for unrecognized aspects of the Earth. Similarly, the contributions by Beacham (forthcoming) and Roux-Rosier et al. (forthcoming) outline actionable alternatives to change our relations to Earth by exploring the varying practices of alternative food networks and permaculture. Perhaps not surprisingly, how we live on the Earth provides important insights about our relationship to the planet. Both these articles thus highlight ways to develop more responsible forms of organizing for both humans and nonhumans.

Returning to the initial aim of this introductory editorial, the five articles in this special issue show how organization studies as a field of inquiry can better engage with the concept of the Anthropocene by problematizing our current path, exploring the politics of our responses, theorizing much needed new forms of organizing, and imagining alternative relations with the planet. The Anthropocene poses fundamental questions about the nature of human existence and the growing complexities of human organizing in a fundamentally different and increasingly hostile world. Grappling with these issues is a complex and difficult task, but one we need to urgently embrace both as organizational scholars and global citizens. 


\section{References}

Ahmed, N. (2014) 'Defence Officials Prepare to Fight the Poor, Activists and Minorities (and Commies)', The Guardian. 13 June, http://www.theguardian.com/environment/earthinsight/2014/jun/13/uk-defence-fight-poor-activists-minorities-marxists-commies.

Albrecht, G., Sartore, G.-M., Connor, L., Higginbotham, N., Freeman, S., Kelly, B., Stain, H., Tonna, A. and Pollard, G. (2007) 'Solastalgia: The Distress Caused by Environmental Change', Australasian Psychiatry 15(s1): S95-S98.

Angus, I. (2016) Facing the Anthropocene: Fossil Capitalism and the Crisis of the Earth System. New York: Monthly Review.

Ansar, A., Caldecott, B. and Tilbury, J. (2013) Stranded Assets and the Fossil Fuel Divestment Campaign: What Does Divestment Mean for the Valuation of Fossil Fuel Assets? Oxford: Smith School of Enterprise and Environment, University of Oxford.

Armstrong, F. (2009) The Age of Stupid, Dogwoof Pictures.

Atwood, M. (2003) Oryx and Crake. London: Bloomsbury.

Atwood, M. (2009) The Year of the Flood. London: Bloomsbury.

Atwood, M. (2013) Maddaddam. London: Bloomsbury.

Bagley, K. (2016) 'For James Hansen, the Science Demands Activism on Climate', Yale Environment 360. 12 April,

https://e360.yale.edu/features/james_hansen_science_demands_action.

Banerjee, B. (2008) 'Necrocapitalism', Organization Studies 29(12): 1541-63.

Bansal, P. and Hoffman, A.J. (eds). (2012) The Oxford Handbook of Business and the Natural Environment. Oxford: Oxford University Press.

Beacham, J. (forthcoming) 'Organising Food Differently: Towards a More-Than-Human Ethics of Care for the Anthropocene', Organization doi:

Biermann, F., Abbott, K., Andresen, S., Bäckstrand, K., Bernstein, S., Betsill, M.M., Bulkeley, H., Cashore, B., Clapp, J., Folke, C., Gupta, A., Gupta, J., Haas, P.M., Jordan, A., Kanie, N., Kluvánková-Oravská, T., Lebel, L., Liverman, D., Meadowcroft, J., Mitchell, R.B., Newell, P., Oberthür, S., Olsson, L., Pattberg, P., Sánchez-Rodríguez, R., Schroeder, H., Underdal, A., Vieira, S.C., Vogel, C., Young, O.R., Brock, A. and Zondervan, R. (2012) 'Navigating the Anthropocene: Improving Earth System Governance', Science 335(6074): 1306-07.

Biermann, F., Bai, X., Bondre, N., Broadgate, W., Arthur Chen, C.-T., Dube, O.P., Erisman, J.W., Glaser, M., van der Hel, S., Lemos, M.C., Seitzinger, S. and Seto, K.C. (2016) 'Down to Earth: Contextualizing the Anthropocene', Global Environmental Change 39: 341-50.

Boykoff, M.T. and Goodman, M.K. (2009) 'Conspicuous Redemption? Reflections on the Promises and Perils of the 'Celebritization' of Climate Change', Geoforum 40(3): 395-406. 
Bradley, J. (2015) Clade. Melbourne: Hamish Hamilton.

Bradshaw, E.A. (2015) 'Blockadia Rising: Rowdy Greens, Direct Action and the Keystone XL Pipeline', Critical Criminology 23(4): 433-48.

Brand, S. (2009) Whole Earth Discipline: An Ecopragmatist Manifesto. New York: Penguin.

Buck, H.J. (2015) 'On the Possibilities of a Charming Anthropocene', Annals of the Association of American Geographers 105(2): 369-77.

Carbon Tracker Initiative. (2012) Unburnable Carbon: Are the World's Financial Markets Carrying a Carbon Bubble? London: CTI.

Carson, R. (1962) Silent Spring. Boston: Houghton Mifflin.

Castree, N. (2015a) 'Changing the Anthropo(s)cene: Geographers, Global Environmental Change and the Politics of Knowledge', Dialogues in Human Geography 5(3): 301-16.

Castree, N. (2015b) 'Geography and Global Change Science: Relationships Necessary, Absent, and Possible', Geographical Research 53(1): 1-15.

Castree, N. (2017) 'Anthropocene: Social Science Misconstrued', Nature 541: 289.

Clark, N. (2014) 'Geo-Politics and the Disaster of the Anthropocene', The Sociological Review 62: 19-37.

Collard, R.-C., Dempsey, J. and Sundberg, J. (2015) 'A Manifesto for Abundant Futures', Annals of the Association of American Geographers 105(2): 322-30.

Crutzen, P.J. (2002) 'Geology of Mankind: The Anthropocene', Nature 415(6867): 23.

Crutzen, P.J. and Stoermer, E.F. (2000) 'Have We Entered the "Anthropocene"?', IGBP Global Change Newsletter 41: 17.

Davis, H. and Turpin, E. (eds). (2015) Art in the Anthropocene : Encounters among Aesthetics, Politics, Environments and Epistemologies. London: Open Humanities Press.

della Porta, D. and Parks, L. (2014) 'Framing Processes in the Climate Movement: From Climate Change to Climate Justice', in M. Dietz and H. Garrelts (eds) Routledge Handbook of the Climate Change Movement, pp. 19-30. Abingdon: Routledge.

Di Chiro, G. (2016) 'Environmental Justice and the Anthropocene Meme', in T. Gabrielson, C. Hall, J.M. Meyer and D. Schlosberg (eds) The Oxford Handbook of Environmental Political Theory, pp. 362-83. Oxford: Oxford University Press.

Dietz, M. and Garrelts, H. (eds). (2014) Routledge Handbook of the Climate Change Movement. Abingdon: Routledge.

Dyer, G. (2010) Climate Wars: The Fight for Survival as the World Overheats. Oxford: Oneworld. 
Ellis, E. (2011) 'The Planet of No Return: Human Resilience on an Artificial Earth', Breakthrough Journal 2: 39-44.

Ellis, E. (2013) 'Overpopulation Is Not the Problem', New York Times. 14 September, http://www.nytimes.com/2013/09/14/opinion/overpopulation-is-not-the-problem.html.

Ergene, S., Calás, M.B. and Smircich, L. (forthcoming) 'Ecologies of Sustainable Concerns: Organization Theorizing for the Anthropocene', Gender, Work \& Organization doi: 10.1111/gwao.12189:

Evans, G. and Phelan, L. (2016) 'Transition to a Post-Carbon Society: Linking Environmental Justice and Just Transition Discourses', Energy Policy 99(Supplement C): 329-39.

Falck, O. and Heblich, S. (2007) 'Corporate Social Responsibility: Doing Well by Doing Good', Business Horizons 50(3): 247-54.

Farber, S.C., Costanza, R. and Wilson, M.A. (2002) 'Economic and Ecological Concepts for Valuing Ecosystem Services', Ecological Economics 41(3): 375-92.

Foster, J. (2015a) After Sustainability: Denial, Hope Retrieval. Abingdon: Routledge.

Foster, J.B. (2000) Marx's Ecology: Materialism and Nature. New York: Monthly Review Press.

Foster, J.B. (2015b) 'The Great Capitalist Climacteric', Monthly Review 67(6): 1-18.

Fox, J. (2010) Gasland, International WOW Company.

Freund, J. (2014) 'The Smiling Faces of Capital and the 3 Vortices of Hell', in S. Brown and S. Ponsonby-McCabe (eds) Brand Mascots: And Other Marketing Animals, pp. 255-66. London: Routledge.

Freund, J. (2015) 'Rev Billy Vs. The Market: A Sane Man in a World of Omnipotent Fantasies', Journal of Marketing Management 31(13-14): 1529-51.

Friedman, M. (1970) 'The Social Responsibility of Business Is to Increase Its Profits'. In New York Times Magazine, 1970, pp. 33.

Funk, M. (2014) Windfall: The Booming Business of Global Warming. New York: Penguin.

Garland, J., Huising, R. and Struben, J. (2013) "'What If Technology Worked in Harmony with Nature?" Imagining Climate Change through Prius Advertisements', Organization 20(5): 679-704.

Gibson Graham, J.K. and Roelvink, G. (2010) 'An Economic Ethics for the Anthropocene', Antipode 41: 320-46.

Gibson, K., Rose, D.B. and Fincher, R. (eds). (2015) Manifesto for Living in the Anthropocene. New York: Punctum Books.

Ginn, F. (2015) 'When Horses Won't Eat: Apocalypse and the Anthropocene', Annals of the Association of American Geographers 105(2): 351-59. 
Gosling, J. and Case, P. (2013) 'Social Dreaming and Ecocentric Ethics: Sources of NonRational Insight in the Face of Climate Change Catastrophe', Organization 20(5): 705-21.

Granada, S. (2017) 'These Artists Are Trying to Make Climate Change Visceral', Outside. 3 August, https://www.outsideonline.com/2229726/these-artists-are-trying-make-climatechange-feel-visceral.

Guggenheim, D. (2006) An Inconvenient Truth, Paramount Classics.

Gupta, J. (2014) The History of Global Climate Governance. Cambridge: Cambridge University Press.

Hamilton, C. (2010) Requium for a Species: Why We Resist the Truth About Climate Change. London: Earthscan.

Hamilton, C. (2013) Earthmasters: Playing God with the Climate. Sydney: Allen \& Unwin.

Hamilton, C. (2015) 'Getting the Anthropocene So Wrong', The Anthropocene Review 2(2): 102-07.

Hamilton, C. (2016) 'Define the Anthropocene in Terms of the Whole Earth', Nature 536: 251.

Hamilton, C. (2017) Defiant Earth: The Fate of Humans in the Anthropocene. Cambridge: Polity Press.

Hamilton, C., Bonneuil, C. and Gemenne, F. (eds). (2015) The Anthropocene and the Global Environmental Crisis : Rethinking Modernity in a New Epoch. London: Routledge.

Hamilton, C. and Grinevald, J. (2015) 'Was the Anthropocene Anticipated?', The Anthropocene Review 2(1): 59-72.

Hansen, J. (2009) Storms of My Grandchildren: The Truth About the Coming Climate Catastrophe and Our Last Chance to Save Humanity. New York: Bloomsbury.

Haraway, D. (2015) 'Anthropocene, Capitalocene, Plantationocene, Chthulucene: Making Kin', Environmental Humanities 6: 159-65.

Hart, S.L. (1995) 'A Natural-Resource-Based View of the Firm', Academy of Management Review 20(4): 986-1014.

Hoffman, A.J. (2001) From Heresy to Dogma: An Institutional History of Corporate Environmentalism. Stanford, CA: Stanford University Press.

Houston, D. (2013) 'Crisis Is Where We Live: Environmental Justice for the Anthropocene', Globalizations 10(3): 439-50.

IEA. (2013) Resources to Reserves 2013: Oil, Gas and Coal Technologies for the Energy Markets of the Future. Paris: International Energy Agency. 
IPCC. (2014) Climate Change 2014: Impacts, Adaptation, and Vulnerability. Part A: Global and Sectoral Aspects. Contribution of Working Group II to the Fifth Assessment Report of the Intergovernmental Panel on Climate Change. Cambridge: Cambridge University Press.

Jackson, R.B., Le Quéré, C., Andrew, R.M., Canadell, J.G., Peters, G.P., Roy, J. and Wu, L. (2017) 'Warning Signs for Stabilizing Global $\mathrm{CO}_{2}$ Emissions', Environmental Research Letters 12(11): 110202.

Jackson, T. (2009) Prosperity without Growth: Economics for a Finite Planet. London: Earthscan.

Jermier, J.M., Forbes, L.C., Benn, S. and Orsato, R.J. (2006) 'The New Corporate Environmentalism and Green Politics', in S.R. Clegg, C. Hardy, T.B. Lawrence and W.R. Nord (eds) The Sage Handbook of Organization Studies, pp. 618-50. London: Sage.

Kalonaityte, V. (forthcoming) 'When Rivers Go to Court: The Anthropocene in Organization Studies through the Lens of Jacques Rancière', Organization doi:

Kaplan, A.E. (2016) Climate Trauma: Foreseeing the Future in Dystopian Film and Fiction. New Brunswick, NJ: Rutgers University Press.

Keller, D.P., Feng, E.Y. and Oschlies, A. (2014) 'Potential Climate Engineering Effectiveness and Side Effects During a High Carbon Dioxide-Emission Scenario', Nature Communications 5: 3304

Kingsnorth, P. and Hine, D. (2009) Uncivilisation: The Dark Mountain Manifesto, Dark Mountain Project, http://dark-mountain.net/about/manifesto/.

Kingsolver, B. (2012) Flight Behavior: A Novel. New York: Harper Collins.

Kitchen, C. (2014) To the Ends of the Earth: A Guide to Unconventional Fossil Fuels. London: Corporate Watch.

Klein, N. (2007) The Shock Doctrine: The Rise of Disaster Capitalism. New York: Picador.

Klein, N. (2014) This Changes Everything: Capitalism Vs. The Climate. New York: Simon \& Schuster.

Kolbert, E. (2014) The Sixth Extinction: An Unnatural History. New York: Henry Holt.

Lederer, M. and Kreuter, J. (forthcoming) 'Organising the Unthinkable in Times of Crises: Will Climate Engineering Become the Weapon of Last Resort in the Anthropocene?', Organization doi: 10.1177/1350508418759186:

Levy, D.L. and Spicer, A. (2013) 'Contested Imaginaries and the Cultural Political Economy of Climate Change', Organization 20(5): 659-78.

Lorimer, J. (2015) Wildlife in the Anthropocene: Conservation after Nature. Minneapolis, MN: University of Minnesota Press.

Lorimer, J. (2017) 'The Anthropo-Scene: A Guide for the Perplexed', Social Studies of Science 47(1): 117-42. 
Lövbrand, E., Beck, S., Chilvers, J., Forsyth, T., Hedrén, J., Hulme, M., Lidskog, R. and Vasileiadou, E. (2015) 'Who Speaks for the Future of Earth? How Critical Social Science Can Extend the Conversation on the Anthropocene', Global Environmental Change 32: 21118.

Lövbrand, E., Stripple, J. and Wiman, B. (2009) 'Earth System Governmentality: Reflections on Science in the Anthropocene', Global Environmental Change 19(1): 7-13.

Malm, A. (2016) Fossil Capital: The Roots of Steam Power and the Roots of Global Warming. London: Verso.

Malm, A. and Hornborg, A. (2014) 'The Geology of Mankind? A Critique of the Anthropocene Narrative', The Anthropocene Review 1(1): 62-69.

Maruyama, Y., Nishikido, M. and Iida, T. (2007) 'The Rise of Community Wind Power in Japan: Enhanced Acceptance through Social Innovation', Energy Policy 35(5): 2761-69.

McKibben, B. (2010) Eaarth: Making a Life on a Tough New Planet. New York: Times Books.

McKibben, B. (2012) 'The Reckoning', Rolling Stone doi: (1162): 52-58,60.

Mol, A.P.J. (2002) 'Ecological Modernization and the Global Economy', Global Environmental Politics 2(2): 92-115.

Moore, J.W. (ed). (2016) Anthropocene or Capitalocene?: Nature, History, and the Crisis of Capitalism. Oakland, CA: PM Press.

Murray, A., Skene, K. and Haynes, K. (2017) 'The Circular Economy: An Interdisciplinary Exploration of the Concept and Application in a Global Context', Journal Of Business Ethics 140(3): 369-80.

New, M., Liverman, D., Schroeder, H. and Anderson, K. (2011) 'Four Degrees and Beyond: The Potential for a Global Temperature Increase of Four Degrees and Its Implications', Philosophical Transactions of the Royal Society A: Mathematical, Physical and Engineering Sciences 369(1934): 6-19.

Newman, P., Beatley, T. and Boyer, H. (2017) Resilient Cities: Overcoming Fossil Fuel Dependence. Washington, DC: Island Press.

Nyberg, D. and Wright, C. (2016) 'Performative and Political: Corporate Constructions of Climate Change Risk', Organization 23(5): 617 -38.

Palsson, G., Szerszynski, B., Sörlin, S., Marks, J., Avril, B., Crumley, C., Hackmann, H., Holm, P., Ingram, J., Kirman, A., Buendía, M.P. and Weehuizen, R. (2013)

'Reconceptualizing the 'Anthropos' in the Anthropocene: Integrating the Social Sciences and Humanities in Global Environmental Change Research', Environmental Science \& Policy 28: 3-13.

Pelto, J. (2017) 'Glaciogenic Art: Communication of Sceintific Research through Art', http://www.jillpelto.com/. 
Porter, M.E. and Kramer, M.R. (2011) 'Creating Shared Value', Harvard Business Review 89(1/2): 62-77.

Porter, M.E. and van der Linde, C. (1995) 'Toward a New Conception of the EnvironmentCompetitiveness Relationship', The Journal of Economic Perspectives 9(4): 97-118.

Potter, W. (2011) Green Is the New Red: The Journey from Activist to "Eco-Terrorist". San Francisco, CA: City Lights.

Quant, H. and Escott, A. (2017) 'The Bureau of Lingustical Reality', https://bureauoflinguisticalreality.com/.

Quinn-Thibodeau, T. and Wu, B. (2016) 'NGOs and the Climate Justice Movement in the Age of Trumpism', Development 59(3): 251-56.

Radkau, J. (2014) The Age of Ecology : A Global History. Cambridge: Polity Press.

Revkin, A. (2014) 'Seeking a 'Good' Anthropocene', Keynote Lecture to the AESS annual conference, Pace University. 13 June, https://www.youtube.com/watch? $=0$ IHeqLKGd3Q.

Rickards, L. (2015) 'Critiquing, Mining and Engaging Anthropocene Science', Dialogues in Human Geography 5(3): 337-42.

Rockström, J., Steffen, W., Noone, K., Persson, Å., Chapin, F.S., Lambin, E.F., Lenton, T.M., Scheffer, M., Folke, C., Schellnhuber, H.J., Nykvist, B., de Wit, C.A., Hughes, T., van der Leeuw, S., Rodhe, H., Sörlin, S., Snyder, P.K., Costanza, R., Svedin, U., Falkenmark, M., Karlberg, L., Corell, R.W., Fabry, V.J., Hansen, J., Walker, B., Liverman, D., Richardson, K., Crutzen, P. and Foley, J.A. (2009) 'A Safe Operating Space for Humanity', Nature 461(7263): 472-75.

Roelvink, G. (2013) 'Rethinking Species-Being in the Anthropocene', Rethinking Marxism 25(1): 52-69.

Roux-Rosier, A., Azambuja, R. and Islam, G. (forthcoming) 'Alternative Visions:

Permaculture as Imaginaries of the Anthropocene', Organization doi:

Russo, M.V. and Fouts, P.A. (1997) 'A Resource-Based Perspective on Corporate Environmental Performance and Profitability', Academy of Management Journal 40(3): 53459.

Schlosberg, D. and Collins, L.B. (2014) 'From Environmental to Climate Justice: Climate Change and the Discourse of Environmental Justice', Wiley Interdisciplinary Reviews:

Climate Change 5(3): 359-74.

Scranton, R. (2015) Learning to Die in the Anthropocene : Reflections on the End of a Civilization. San Francisco, CA: City Lights.

Shellenberger, M. and Nordhaus, T. (2004) The Death of Environmentalism: Global Warming Politics in a Post-Environmental World, Oakland CA, The Breakthrough Institute, http://www.thebreakthrough.org/images/Death_of_Environmentalism.pdf. 
Shellenberger, M. and Nordhaus, T. (eds). (2011) Love Your Monsters:

Postenvironmentalism and the Anthropocene. Oakland, CA: Breakthrough Institute.

Smith, A. (2011) 'The Transition Town Network: A Review of Current Evolutions and Renaissance', Social Movement Studies 10(1): 99-105.

Steffen, W., Crutzen, P.J. and McNeill, J.R. (2007) 'The Anthropocene: Are Humans Now Overwhelming the Great Forces of Nature?', AMBIO: A Journal of the Human Environment 36(8): 614-21.

Steffen, W., Leinfelder, R., Zalasiewicz, J., Waters, C.N., Williams, M., Summerhayes, C., Barnosky, A.D., Cearreta, A., Crutzen, P., Edgeworth, M., Ellis, E.C., Fairchild, I.J., Galuszka, A., Grinevald, J., Haywood, A., Ivar do Sul, J., Jeandel, C., McNeill, J.R., Odada, E., Oreskes, N., Revkin, A., Richter, D.d., Syvitski, J., Vidas, D., Wagreich, M., Wing, S.L., Wolfe, A.P. and Schellnhuber, H.J. (2016) 'Stratigraphic and Earth System Approaches to Defining the Anthropocene', Earth's Future 4(8): 324-45.

Stern, N. (2007) The Economics of Climate Change: The Stern Review. Cambridge: Cambridge University Press.

Stevens, F. (2016) Before the Flood, National Geographic.

Stone, C.D. (1974) Should Trees Have Standing? Toward Legal Rights for Natural Objects. Los Altos, CA.: W. Kaufmann.

Szerszynski, B., Kearnes, M., Macnaghten, P., Owen, R. and Stilgoe, J. (2013) 'Why Solar Radiation Management Geoengineering and Democracy Won't Mix', Environment and Planning A 45(12): 2809-16.

Tollefson, J. (2017) 'Trump EPA Begins Push to Overturn Obama-Era Climate Regulation', Nature 550(7676): 311.

Topham, G. (2016) 'Heathrow 13 Likely to Become UK's First Climate Change Protesters to Be Jailed', The Guardian. 24 February, https://www.theguardian.com/environment/2016/feb/24/heathrow-13-likely-to-become-uksfirst-climate-change-protesters-to-be-jailed.

Trexler, A. (2015) Anthropocene Fictions: The Novel in a Time of Climate Change. Charlottesville: University of Virginia Press.

Uhrqvist, O. and Lövbrand, E. (2014) 'Rendering Global Change Problematic: The Constitutive Effects of Earth System Research in the Igbp and the Ihdp', Environmental Politics 23(2): 339-56.

Ullrich, J.K. (2015) 'Climate Fiction: Can Books Save the Planet?', The Atlantic. 14 August, https://www.theatlantic.com/entertainment/archive/2015/08/climate-fiction-margaret-atwoodliterature/400112/.

van der Schoor, T. and Scholtens, B. (2015) 'Power to the People: Local Community Initiatives and the Transition to Sustainable Energy', Renewable and Sustainable Energy Reviews 43(Supplement C): 666-75. 
Vidal, J. (2014) 'Arctic 30: Russia Releases Greenpeace Ship', The Guardian. 6 June, https://www.theguardian.com/environment/2014/jun/06/arctic-30-sunrise-russia-to-releasegreenpeace-ship.

Whiteman, G., Walker, B. and Perego, P. (2013) 'Planetary Boundaries: Ecological Foundations for Corporate Sustainability', Journal of Management Studies 50(2): 307-36.

Williams, T.T. (2012) 'What Love Looks Like', Orion Magazine. January/February, https://orionmagazine.org/article/what-love-looks-like/.

Wissman-Weber, N. and Levy, D. (forthcoming) 'Climate Adaptation in the Anthropocene: Constructing and Contesting Urban Risk Regimes', Organization doi:

Wright, C. and Nyberg, D. (2015) Climate Change, Capitalism and Corporations: Processes of Creative Self-Destruction. Cambridge: Cambridge University Press.

Yusoff, K. and Gabrys, J. (2011) 'Climate Change and the Imagination', Wiley Interdisciplinary Reviews: Climate Change 2(4): 516-34. 